\title{
Assessment of phosphate and potash states of virgin, tillable and recultivated soils
}

\author{
Yeterevska L. ${ }^{1}$, Khrystenko A. ${ }^{2}$, Momot H. ${ }^{3}$, Akimova R. ${ }^{4}$ \\ NSC "A.N. Sokolovsky Institute of soil science and agrochemistry», Chaikovska Str., 4, Kharkiv, 61024,

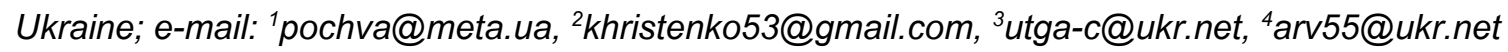

The purpose. To state an exact assessment of phosphate and potash states of virgin and tillable natural soils, recultivated soils of different lithologic content (long fallow). Methods. Statistical-mathematical analysis of materials of automized data bank of agrochemical properties of soils. Results. Regularities of formation of phosphate and potash states of natural and recultivated soils of different coenosises are established. Dynamics of changes of values of security of these soils with movable joints of phosphorus and potassium under the influence of various factors is resulted. It is proved that natural content of accessible to plants nutrients in virgin and idle lands sometimes attains very tall values exceeding optimum. But such content of nutrients is characteristic only for layer of sod or the upper humus (humus-accumulative) horizon of soils. Trophic systems of virgin (long fallow) soils after their ploughing up are characterized by low values of indexes. Conclusions. The major role in building system which enables to sustain tall phosphate and potash levels of soils, play active forms of humus. Increase of content of again organized organic substance during 13 years promoted essential heightening of security of top layer $(0-5 \mathrm{~cm})$ of recultivated soils with movable joints of phosphorus and potassium. The heavier was granulometric composition of sod-lithogenic soils, and the more it contained humus matters, the more intensive they accumulated phosphorus and potassium. In conditions of turfy soil formation with its activation by grain-bean components recultivated soils in due course can become a redundancy for building productive agricultural lands.

Key words: virgin soils, arable soils, technogenic soils, recultivation, phosphate state, potash state, humus, pedogenesis.

\section{DOI: https://doi.org/10.31073/agrovisnyk201905-07}

Introduction. So far, the issue of the formation of the trophic state of soils of different coenoses (the orientation of processes and the change in the values of indicators) remains controversial, despite the long history of their study [14]. The trophic state of virgin, fallow and reclaimed (technogenic) soils is the least studied. Meanwhile, knowledge of the patterns of formation and the state of the trophic state of natural and technogenic soils is an important necessary condition for understanding the evolution of phosphate, potassium and other soil systems and the development of practical recommendations for the optimization of agricultural use of such soils.

The study of the processes of primary soil formation will allow to determine the values of the speed of soil formation and humus accumulation, to develop mechanisms for managing this process in technogenically damaged soils, which is necessary for the development of rational land reclamation measures and the adoption of grounded management decisions regarding land use [5].

The gross chemical composition of the mineral part of the soil is inherited from the deflation crust, and also expresses the nature of the processes of soil formation. It is a function of granulometric, and as a consequence - mineralogical composition. The content of individual elements in the soil is determined by their presence of specific minerals and organic compounds in the content [6].

In general, the formation of the main properties of technogenic soils, in contrast to the formation of their characteristics, depends on the source material, from which the soil is formed, age of phytocoenosis, climatic conditions and the relief of each technogenic landscape.

Aim of research. To give an accurate assessment of the phosphate and potassium states of virgin, arable and reclaimed soils, wich are used extensively.

Materials and methods of research. Statistical analysis and generalization of the data of the automated database of agrochemical properties of soils were carried out on the base of the Access 98 database. The information bank contains data from analyzes of about 2000 samples of different soils.

Object of research is the reclaimed soils of the Novoselivsky Model Range (Novovodolazhsky District, Kharkiv Oblast) with a capacity of $1 \mathrm{~m}$. Three models are soddy-lithogenic soils, formed from: 1 - loess loam, 2 a mixture of forest loam and sand (1: 1), 3 - a mixture of red-brown clay and sand (1: 1). 
There are two models: pedozems consisting of: 4 - a mixture of a humus layer of soil and loam (1:1) in a layer of 0-40 cm, a deeper blast of non-toxic rocks, 5 - a humus layer of soil 0-60 cm, a deeper blasting mixture. The vegetation cover at the polygon was created in the year of its formation by the initial seeding of a 6-component cereal-bean mixture of blue-hybrid alfalfa, sainfoin sandy, pink clover, bromus inermis, agrostis capillaris; the proportion of beans and cereal components - 50:50\%. After 18 years, there has been a radical improvement in herbage using 4-component cereal-bean grass mix. Years of research - 7-20 years of the polygon functioning.

Research results. The natural amount of mobile compounds of phosphorus and potassium in an arable layer of soils, as a rule, is characterized by low values. Visibility of various (from very low to very high) natural provision of arable soils due to these nutrition elements is due to the fact that the dominant methods in conducting the soil survey, to this time remain "hard" methods. These include, first of all, methods based on acid extractants: Kirsanov $(\mathrm{pH}=$ 1.0), Brau-Kurtz 2 (pH-1.0), Mehlich 1 ( $\mathrm{pH}-1.2)$, Arrhenius (pH-2 ( $\mathrm{PH} 3.0)$, Egner-Riehm (pH 3.6), Egner-RiehmDomingo (pH 3.0), Chirikov (pH 2.5), Van Lierop (Kelowna - pH 2.7), Truog (pH 3.0), Egner-Riehm (pH 4,2) and others.

The use of "hard" methods allows obtaining an objective assessment of the fertility of soils with certain properties, namely the soils for which the group was developed to provide them with phosphorus or potassium. First of all, it has the following properties: certain values of the content of physical clay and apatite, as well as the $\mathrm{pH}$ value of soil [7].

The analysis of the phosphate state of the soils, which are in the virgin state or under the fallow, has shown that in most cases such a state has a fundamental difference from their unfertilized arable analogues. Namely: the natural content of the amount of available phosphorus to plants can reach very high values, which in 4-6 times or more exceed the optimal ones (Table 1).

Table 1. Phosphate state of the upper humus horizon $(5-16 \mathrm{~cm})$ of virgin or permafrost soils

\begin{tabular}{|c|c|c|c|c|c|}
\hline \multirow{3}{*}{ Soil } & \multirow{3}{*}{$\begin{array}{lr}\text { Content } & \text { of } \\
\text { physical } & \text { clay, } \\
\% & \end{array}$} & \multicolumn{4}{|c|}{ Content of P2O5 } \\
\hline & & gross & by Chirikov & by Olsen & by Karpinsky-Zamyatina \\
\hline & & \multicolumn{4}{|l|}{$\mathrm{mg} / \mathrm{kg}$ of soil } \\
\hline Gray forest & 26,5 & 970 & 179 & 94 & 2,5 \\
\hline Chernozem typical & 26,9 & 1560 & 242 & 106 & 7,4 \\
\hline Chernozem ordinary & 40,8 & 1400 & 269 & 95 & 3,9 \\
\hline Meadow chernozem & 31,5 & 2640 & 1270 & 225 & 15,6 \\
\hline Dark chestnut & 55,2 & 1460 & 193 & 59 & 1,3 \\
\hline
\end{tabular}

A similar pattern is inherent in the potassium state of soils.

At the same time, high content of mobile compounds of phosphorus or potassium is characteristic only for the layer of turf or upper humus (humus-accumulative) horizon of soils (Table 2).

The highest content of mobile phosphorus ( $174.0 \mathrm{mg} \mathrm{P} \mathrm{P}_{2} \mathrm{O}_{5} / \mathrm{kg}$ of soil byChirikov, $9.0 \mathrm{mg} \mathrm{P} \mathrm{P}_{2} \mathrm{O}_{5} / \mathrm{kg}$ of soil by Karpinsky-Zamyatin) and, in particular, potassium (564 mg K ${ }_{2} \mathrm{O} / \mathrm{kg}$ of soil by Chirikov) was observed in turf. Down the profile, with a decrease in the content of organic matter, especially its labile part (by Yegorov), the content of $\mathrm{P}_{2} \mathrm{O}_{5}$ and $\mathrm{K}_{2} \mathrm{O}$ sharply decreases.

Table 2. Content of organic matter, as well as $\mathrm{P}_{2} \mathrm{O}_{5}$ and $\mathrm{K}_{2} \mathrm{O}$ by Chirikov in different layers of dark gray, podzolized soil (fallow)

\begin{tabular}{|c|c|c|c|c|}
\hline \multirow{2}{*}{$\begin{array}{l}\text { Layer of } \\
\text { soil, } \mathrm{cm}\end{array}$} & $\begin{array}{l}\begin{array}{l}\text { Content of } \\
\text { humus }\end{array} \\
\end{array}$ & Content of labile organic matter & Content of $\mathrm{P}_{2} \mathrm{O}_{5}$ & Content of $\mathrm{K}_{2} \mathrm{O}$ \\
\hline & \multicolumn{2}{|l|}{$\%$} & \multicolumn{2}{|l|}{$\mathrm{mg} / \mathrm{kg}$ of soil } \\
\hline $0-2$ & 4,9 & 0,75 & 174 & 564 \\
\hline $2-10$ & 3,8 & 0,48 & 109 & 108 \\
\hline $10-20$ & 3,3 & 0,41 & 47 & 73 \\
\hline $20-30$ & 1,8 & 0,14 & 40 & 70 \\
\hline
\end{tabular}

It can be noted that the natural semi-hydromorphous soils (meadow, meadow and chernozem ones), as well as chernozem typical, light and medium loamy have the most favorable phosphate state. Predominantly, these are soils of the Forest-Steppe zone with high content of organic matter.

We can say that low-soluble phosphorus compounds of the upper humus (humus-accumulation) horizon transfering in moving forms, as well as phosphates coming from lower horizons (bioprecipitation), do not return to thermodynamically stable compounds in virgin soils. 
Of course, active forms of humus substances play an important role in the creation of such a system. It is well known, that the flow of free energy, which compensates for the production of entropy in biological and chemical processes, is ensured by the input into the soil of organic matter [8].

It is believed that humus substances neutralize positive charges on the surface of clay minerals, bind active cations of iron, aluminum, and, respectively, block the fixation of phosphoric acid anions. The mobilizing effect on mineral phosphates is given by specific humus (fulvic acids) and non-specific organic substances [9].

Thus, phosphate and potassium systems of virgin soils, due to high and constantly renewables free energy, can exist for a long time in an energy-disadvantageous nonequilibrium state. It can be assumed that after the plowing of these soils, as a result of the partial mineralization of the humus substances and the destruction of the formed structure, their phosphate and potassium systems will very quickly (over several years) reach the state of typical unfertilized arable soils - that is, with low indicators of their availability of nutrients.

Indeed, the plowing of the fallow soils causes a significant change in the water, thermal, microbiological and other soil conditions. It leads to a significant dynamics of a number of soil indicators, and above all, a decrease in the content of organic matter by $10-40 \%$. This, in turn, leads to a sharp deterioration of the phosphate state of soil (Table 3).

Table 3. Dynamics of indicators of the phosphate state of the fallow soils before and after plowing

\begin{tabular}{|l|l|l|l|}
\hline \multirow{2}{*}{ Soil } & \multirow{2}{*}{$\begin{array}{l}\text { Gross } \\
\text { phosphorus }\end{array}$} & Olsen & Content of $\mathrm{P}_{2} \mathrm{O}_{5}, \mathrm{mg} / \mathrm{kg}$ of soil by: \\
\cline { 3 - 4 } & & & Karpinsky-Zamyatina \\
\hline Fallow & & & \\
\hline Meadow chernozem & 162 & 60 & 1,6 \\
Chernozem typical & 146 & 129 & 4,8 \\
Chernozem ordinary & 140 & & 35 \\
\hline Unfertilized plowing & & & 0,4 \\
\hline Meadow chernozem & 153 & 22 & 0,4 \\
Chernozem typical & 144 & 19 & 0,3 \\
Chernozem ordinary & 106 & 20 & 0,1 \\
\hline HIP05 & 28 & 12 & \\
\hline
\end{tabular}

At the same time, the content of $\mathrm{P}_{2} \mathrm{O}_{5}$, according to the data by Olsen and Karpinsky-Zamyatin methods, approaches the level corresponding to the level of dynamic equilibrium of the phosphate systems of arable soils.

In the case of technogenic soils, a comprehensive assessment of their phosphate and potassium status was carried out on the example of the Novoselivsky model polygon, showing the following.

At the beginning of the research, the content of phosphorus in the upper layer of rocks, their mixtures and the humus layer of soil was on the border of low and medium, and, potassium - medium availability (Table 4). In fact, litozems (without a humus layer of soil) are always characterized by a low initial level of the availability of mobile forms of nutrients.

Table 4. Indicators of fertility of technogenic soils, layer $0-5 \mathrm{~cm}$. Output data, 7 th year of operation of the polygon

\begin{tabular}{|c|c|c|c|c|c|}
\hline \multirow[t]{2}{*}{ Option } & \multirow{2}{*}{$\begin{array}{l}\text { Humus } \\
\text { content, } \%\end{array}$} & \multirow[t]{2}{*}{$\mathrm{pH}_{\mathrm{H} 2 \mathrm{O}}$} & \multicolumn{2}{|c|}{ Content of $\mathrm{P}_{2} \mathrm{O}_{5}, \mathrm{mg} / \mathrm{kg}$, by } & \multirow{2}{*}{$\begin{array}{lr}\text { Content of } & \mathrm{K}_{2} \mathrm{O}, \\
\mathrm{mg} / \mathrm{kg} & \text { by } \\
\text { Machygin } & \end{array}$} \\
\hline & & & Machygin & Karpinsky-Zamyatina & \\
\hline model 1 & 0,71 & 8,2 & 14,8 & 0,25 & 106 \\
\hline model 3 & 1 & 8 & 15,2 & 0,25 & 148 \\
\hline model 4 & 1,6 & 7,9 & 11,7 & 0,20 & 103 \\
\hline model 5 & 2,36 & 7,9 & 26,7 & 0,30 & 150 \\
\hline
\end{tabular}


The low stocks of phosphorus and potassium compounds available to plants at the initial stages of the development of nitrogen are a limiting factor that necessitates the use of fertilizers. Unfortunately, at present the cost of phosphorus and potassium fertilizers obtained from imported raw materials is very high.

But, as was proved by the example of virgin and fallow soils, there is a way to increase the trophic level of soils by natural means, namely the creation of continuously functioning perennial grasses and leguminous agrocenoses that contribute to the activation of the sod process. The disadvantage of this method is the excessive duration of this process.

With natural overhang of dumps and carrying out of recultivation works the formation of soils occurs according to zonal type. The process of accumulation of humus in technogenic soils, which are concentrated near high-yielding natural landscapes, with close biogeochemical and biogeocoenic bonds, close chemical composition of vegetation and factors of its degradation and microbial transformation, should be very close to the zonal type [10].

The most evolving and informative process in the formation of soils of technogenic landscapes is humus formation, in which the transformation of the mineral part of rocks has a directed character and depends on the primary groups of the initial stages of succession [10].

According to numerous data, the content of humus and the rate of its formation in the upper cumulative layer of man-made soils under different vegetation is uneven. The main indicators characterizing the speed and direction of the soil-forming process are the indicators of carbon accumulation in different horizons of the reclamation layer and the qualitative composition of the formed soils.

In the studied technogenic soils, the content of total humus from 7 to 20 years of operation of the polygon, increased very slowly. But in the upper layer of $0-5 \mathrm{~cm}$, where the formation of turf began, the content of humus significantly increased: from $0,71-2,36 \%$ to $1,91-3,1 \%$, ie in $1,3-3,1$ times (Table 5).

Table 5. Indicators of fertility of technogenic soils, layer $0-5 \mathrm{~cm}$, the 20th year of operation of the landfill

\begin{tabular}{|c|c|c|c|c|c|c|}
\hline \multirow[t]{2}{*}{ Option } & \multirow{2}{*}{$\begin{array}{l}\text { Humus } \\
\text { content, \% }\end{array}$} & \multirow[t]{2}{*}{$\mathrm{pH}_{\mathrm{H} 2 \mathrm{O}}$} & \multirow{2}{*}{$\begin{array}{l}\text { Content of } \\
\text { physical } \\
\text { clay, \% }\end{array}$} & \multicolumn{2}{|c|}{ Content of $\mathrm{P} 2 \mathrm{O} 5, \mathrm{mg} / \mathrm{kg}$, by } & \multirow{2}{*}{$\begin{array}{lr}\text { Content of } & \mathrm{K}_{2} \mathrm{O}, \\
\mathrm{mg} / \mathrm{kg} & \text { by } \\
\text { Machygin } & \end{array}$} \\
\hline & & & & Machygin & $\begin{array}{l}\text { Karpinsky- } \\
\text { Zamyatina }\end{array}$ & \\
\hline model 1 & 2,21 & 8,2 & 52 & 30,4 & 0,8 & 146 \\
\hline model 3 & 1,91 & 7,9 & 44 & 22,3 & 0,8 & 147 \\
\hline model 4 & 2,65 & 8 & 53 & 25,2 & 0,6 & 146 \\
\hline model 5 & 3,1 & 7,9 & 58 & 76,0 & 1,8 & 266 \\
\hline
\end{tabular}

The increase of humus content contributed to a significant increase in the availability of this layer with mobile phosphorus and potassium compounds.

The content of mobile phosphorus by Machygin increased 1.4-2.8 times depending on the model. That is, phosphate availability of this layer of soil for just 13 years has increased from low to medium and even high. Moreover, the more technogenic soil contained humus substances, the more phosphorus was accumulated. The correlation coefficient $(r)$ was 0.80 .

An increase in the content of mobile phosphorus is also directly related to the amount of physical clay:

$$
y=-121,8387+2,7645 X \quad r=0,94
$$

where $\mathrm{Y}$ - increase of content $\mathrm{P}_{2} \mathrm{O}_{5}, \mathrm{mg} / \mathrm{kg}$; X- content of physical clay, $\%$.

With regard to deeper layers of soil, a slight significant increase in the content of mobile phosphorus was observed in the layer $5-10 \mathrm{~cm}$ only on model 5 (humus layer of soil), Table 1. 


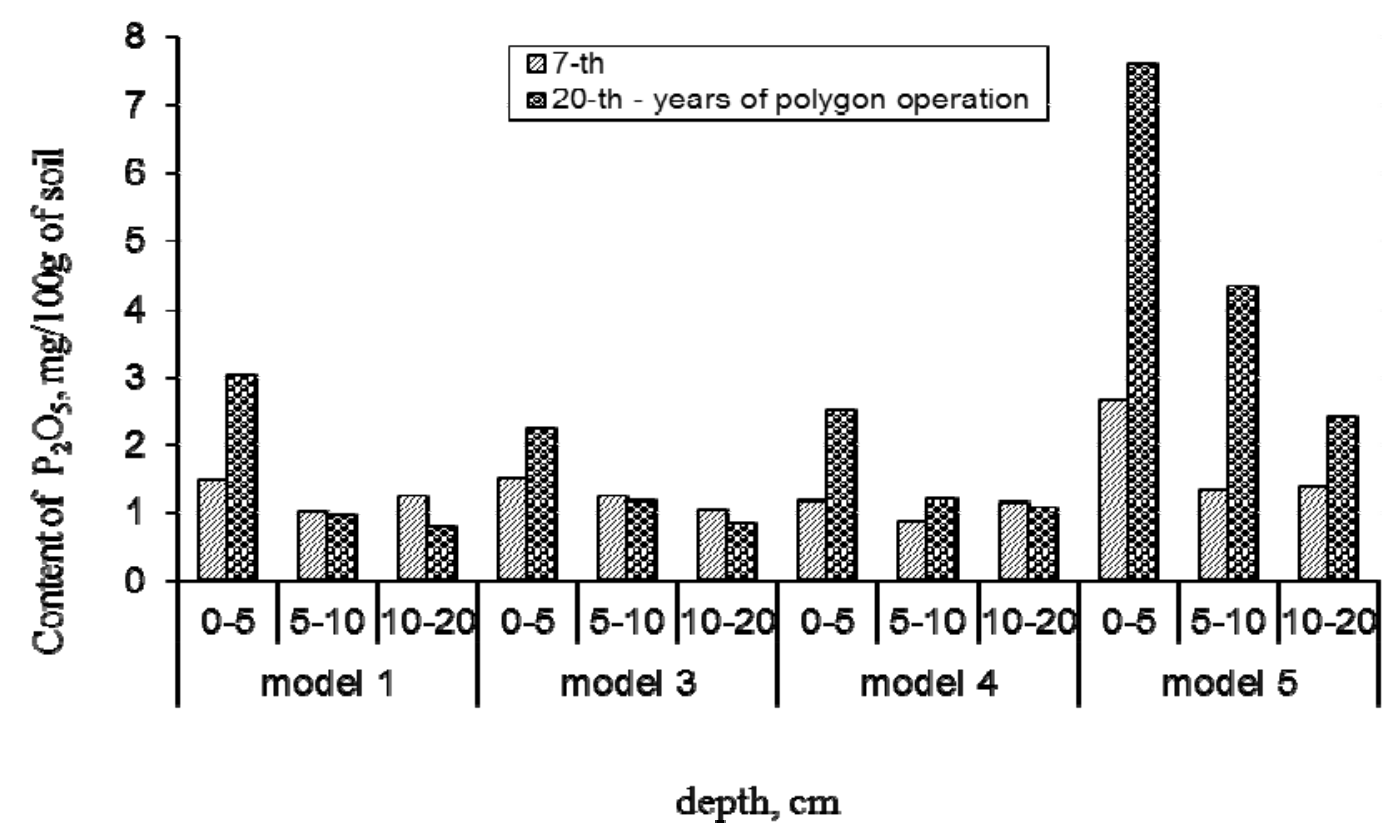

Figure 1. Content of $\mathrm{P}_{2} \mathrm{O}_{5}$ by Machigin in technogenic soils of the Novoselivsky Model Polygon

The content of mobile potassium during 13 years of research was not increased only on model 3 (a mixture of red-brown clay and sand). On other models, depending on their composition, the content of $\mathrm{K}_{2} \mathrm{O}$ increased by 1,4-1,8 times, but increased potassium content was characterized only by the soil of model 5 . However, the increase in potassium levels on other models was small but statistically significant. The correlation coefficient $(r)$ between the amount of humus and potassium content was 0.74 .

On models 4 and 5 there was a certain increase in the content of mobile potassium and in a layer of $5-10 \mathrm{~cm}$ (Fig. 2).

This fact needs to be checked, since the reliability of such an increase in $\mathrm{K}_{2} \mathrm{O}$ content in conditions of minimal increase of humus content, causes some doubts.

Formation of phosphorus and potassium compounds available to plants is sufficient for the gradual creation of a fertile layer suitable for growth and development of crops and, first of all, perennial grasses.

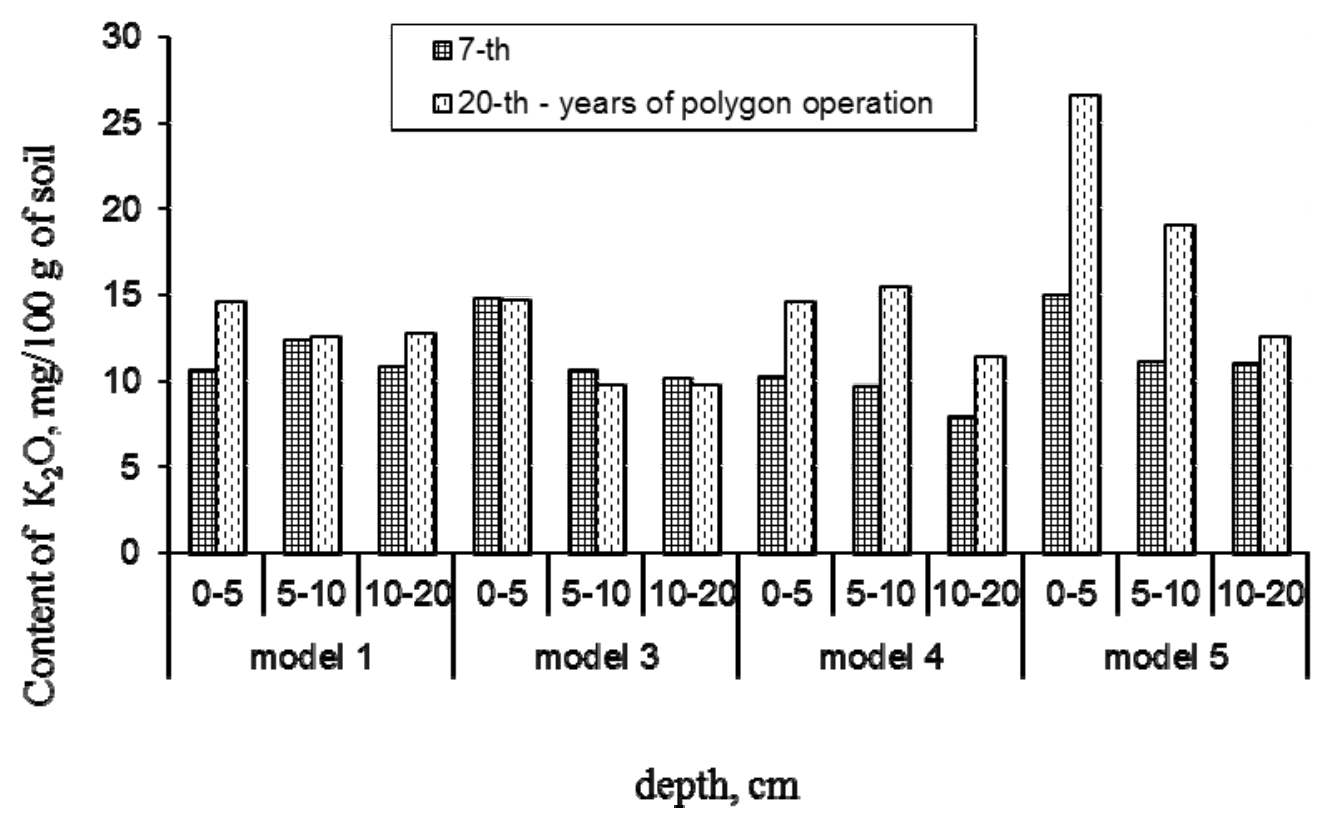

Figure 2. Content of $\mathrm{K}_{2} \mathrm{O}$ by Machygin in technogenic soils of the Novoselivsky Model Polygon 
It is possible to assume with high probability that using, in this case, small doses of nitrogen fertilizers (N1015), could significantly accelerate the process of soil formation. But this is a separate issue that requires additional study.

\section{Conclusions}

The phosphate and potassium state of the virgin or fallow soils is fundamentally different from their unfertilized arable analogues. The natural content of nutrients available to plants in the soils of these cenoses can reach very high values, which may exceed the optimal ones. However, such nutrient content is characteristic only for the layer of turf or the upper humus (humus-accumulative) horizon of soils.

The most important role in the formation of this system is played by active forms of humus substances: precisely because of the input into the soil of organic matter, the flow of free energy is provided, which compensates for the production of entropy in biological and chemical processes. As a result, the phosphate and potassium systems of the upper horizon of virgin soils, due to high and constantly renewable free energy reserves, can exist for a long time in an energy-disadvantageous non-equilibrium state.

The trophic systems of virgin (fallow) soils, after their plowing, lose the ability to maintain a high level of nutrient content and, after a certain time (several years), are approaching the state of the characteristic for extensively used arable soils, which are characterized by low values of the indicators.

In technogenic soils, the content of total humus for 13 years of research has increased significantly only in the upper $0-5 \mathrm{~cm}$ layer. The growth of humus content contributed to a significant increase in the content of mobile phosphorus and potassium.

The phosphorus availability of this layer of soil has increased from low to medium and even high values. Moreover, the heavier granulometric composition of turf-lithogenic soil was and the more it contained humus substances, the more phosphorus and potassium accumulated.

These facts indicate that, in the conditions of the sod process of soil formation with the activation of its grainbean component, recultivated soils can eventually become a reserve for the creation of productive agricultural lands.

\section{References}

1. Khristenko A.A. (2014). Teoreticheskie aspektyi troficheskogo sostoyaniya pochv i zakonomernostey ego evolyutsii. [Theoretical aspects of the trophic state of the soil and the laws of its evolution]. Agrochemistry and Soil Science. Special issue. Book 1. P. 172-179. [in Russian].

2. Smagin A.V., Belyuchenko I.S., Sadovnikova N.B. (2016). Chernozemyi Rossii: estestvennaya dinamika i agrodegradatsiya. Pochvovedenie-prodovolstvennoy i ekologicheskoy bezopasnosti stranyi: tezisyi dokladov VII sezda Obschestva pochvovedov im. V.V. Dokuchaeva i Vserossiyskoy s mezhdunarodnyim uchastiem nauchnoy konferentsii. [Chernozems of Russia: natural dynamics and agrodegradation. Soil science - food and environmental security of the country: abstracts of the reports of the VII Congress of the Society of Soil Science named after V.V. Dokuchaev and Russian international scientific conference]. Moscow-Belgorod: Publishing House "Belgorod". Part II. P. 167-168. [in Russian].

3. Hladkikh Ye.Yu. (2018). Zakonomirnosti sezonnoyi dinamlki elementiv zhivlennya ta osoblivostey yihnogo pererozpodilu $v$ grunti zalezhno vid gidrotermichnyh umov roku. [Patterns of seasonal dynamics of nutrition elements and the peculiarities of their redistribution in the soil depending on hydrothermal conditions of the year]. Agrochemistry and Soil Science. Special issue. Book 2. P. 145- 147. [in Ukrainian].

4. Hospodarenko H.M., Stanisevich O.Yu., Boiko V.P. (2018). Vplyv spivvidnoshennya vidiv i doz mineralnyh dobryv na fosfatnyi rezhim chornozemu opidzolenogo. [Influence of correlation of types and doses of mineral fertilizers on the phosphate regime of chernozem podzolized]. Agrochemistry and Soil Science. Special issue. Book 2. P. 151-153. [in Ukrainian].

5. Karpova D.V, Chizhikova N.P., Ivanova E.A., Mitireva E.A., Husnetdinova T.I., Starokozhko N.A., Korotaeva V.V. (2016). Izmenenie svoystv pochv otvalov Mihaylovskogo GOKa (KMA) v zavisimosti ot dlitelnosti osvoeniya. Pochvovedenie-prodovolstvennoy i ekologicheskoy bezopasnosti stranyi: tezisyi dokladov VII sezda Obschestva pochvovedov im. V.V. Dokuchaeva i Vserossiyskoy s mezhdunarodnyim uchastiem nauchnoy konferentsii. [Change in soil properties of Mikhailovsky GOK dumps depending on the duration of its mastering. Soil science - food and environmental security of the country: abstracts of the reports of the VII Congress of 
the Society of Soil Science named after V.V. Dokuchaev and Russian international scientific conference]. Moscow-Belgorod: Publishing House "Belgorod". Part II. P. 434-435. [in Russian].

6. Dmytrenko P.A. (1948). O formah fosfatov $\mathrm{i}$ ih uchete $v$ osnovnyih tipah pochv USSR. [On the forms of phosphates and their accounting in the main types of soils of the Ukrainian SSR]. Soil science. № 8. P. 36-46. [in Russian].

7. Khristenko A. (2017). Theoretical Problems of improving Agrochemical Terminology. Soil Science Working for a Living, Chapter 12. Springer - DOI 10.1007/978-3-319-45417-7_12. P. 141-147.

8. Trofimov S. Ya., Sedov S. N. (1997). Funktsionirovanie pochv v biogeotsenozah: podhodyi k opisaniyu i analizu. Soil [Functioning in Biogeocenoses: Approaches to Description and Analysis]. Soil science. № 6. P. 770-778. [in Russian].

9. Brosard M., Laurent J. I. (1988). Matiere organique et formes organiques et minerals de stockage du phosphore dans un vertisol. Journees pedologiques ORSTOM. Ser. Pedol. Vol. 24. № 4. P. 347-349.

10. Trofimov S.S. (1977). Rekultivatsiya i pochvoobrazovanie. Problemyi sibirskogo pochvovedeniya. [Reclamation and soil formation. Problems of Siberian soil science] Novosibirsk: Science, Siberian Branch. P. 52-73. [in Russian]. 